\title{
ИГРАЊЕ ИЛИ УЧЕЊЕ: НЕПОМИРЕНИ ДУАЛИТЕТИ У СТАВОВИМА УЧЕСНИКА НАСТАВНОГ ПРОЦЕСА ${ }^{2}$
}

Савремена настава језика за циљ поставља усавршавање свих језичких компетенција како би кандидат постао успешан и самосталан корисник циљног језика. Иако су ове идеје присутне на различитим нивоима језичког образовања, резултати овог квалитативног истраживања, спроведеног током реформе студијских програма на Филолошком факултету у Београду, указују да не постоји увек суштинско разумевање поменутих принципа, што понекад води њиховој контрадикторној интерпретацији. Наиме, није довољно да предавачи и студенти буду упознати са савременим токовима науке о језику јер то не утиче на промену њиховог приступа настави, односно учењу језика. Од кључне је важности створити услове да учесници преиспитају своја дубока уверења и ставове о образовању, како би се и њихово деловање суштински променило.

Кључне речи: игралачко учење, комуникативна настава, настава страних језика, образовна идеологија, ставови, учење граматике.

\section{1. Увод}

Увек актуелно питање улоге образовања одражава специфичне идеологије учесника образовног процеса, али и свих оних који о образовању уопште размишљају. Уверења о сврси образовања, улогама учесника наставног процеса, активностима које подстичу учење или га ометају присутна су на различитим нивоима - као што су национални, регионални,

anajovano@gmail.com

Рад је настао у оквиру пројекта 178014 „Динамика структура савременог српског језика", који финансира Министарство просвете, науке и технолошког развоја Републике Србије. 
Ана Јовановић

институционални, индивидуални - и снажно утичу на све аспекте образовног процеса (Миган, Харбер 2007: 216), али и на скривени курикулум који прикривено управља поступцима образовних актера (в. Жиру, Парпел 1983). Улога скривеног курикулума можда је и дефинишућа у доба кризе образовања током кога долази до преиспитивања образовних идеологија, разматрања алтернативних теоријских поставки и увођења нових решења. Нови модели се сукобљавају са претходним, релативизују их и доводе у питање што свакако ствара тензије на свим нивоима образовања, па тако и у систему уверења и вредности учесника образовног процеса (в. Јовановић 2009, Јовановић 2012, Јовановић 2016).

У наставку овог рада ће се укратко представити епистемолошки оквир конструктивизма који се доводи у везу са савременом наставом страних језика у Србији, а који даје оквир за анализу поменутих тема са становишта учесника у настави, предавача и студената шпанског језика Филолошког факултета у Београду. Резултати изложени у раду заснивају се на подацима прикупљеним током квалитативног истраживања спроведеног током реформе студијских програма на Филолошком факултету у Београду, те тако бацају светло на динамични сусрет две образовне идеологије оличене у старом и новом наставном програму. У анализи и интерпретацији квалитативних података са посматрања часова, бележака са терена и из интервјуа са предавачима и студентима коришћена је методологија која се води егзистенцијалним искуствима учесника, тј. њиховим опажањима, делима, ставовима и осећањима према настави језика (Јовановић 2009: 139).

\section{2. Конструктивизам и настава језика}

Последњих неколико деценија свакако представљају нову прекретницу у образовању на глобалном нивоу где се ранији позитивистички оквир сусреће и одмерава са новим епистемолошким моделом који се, у контексту учења и наставе, може 
ИГРАњЕ ИЛИ УЧЕЊЕ: НЕПОМИРЕНИ ДУАЛИТЕТИ У СТАВОВИМА...

довести у везу са конструктивизмом (Јовановић 2016, Јовановић 2017). Конструктивизам, суштински, претпоставља да ученици активно стварају знање кроз креативне процесе и учешће у друштвеној интеракцији. У том контексту, преиспитују се сви аспекти наставног процеса, па и улога игре и игралачког учења у формалном образовању. Штавише, на Јејл универзитету је 2005. године одржана конференција под називом „Игра = учење“ као реакција на доминантан систем образовања заступљен у већини развијених замаља света. Један од основних закључака указује да образовање, које је усмерено на усвајане изолованих чињеница и занемаривање игралачког учења, покреће низ проблема код деце и младих у модерном свету (Голинкоф, Сингер, Хирш-Песек 2006). Аутори указују да је, између осталог, игра значајна за развој друштвене компетенције и самопоуздања (Сингер, Сингер 2005). Па ипак, иако међу истраживачима и наставницима већ дуго постоји свест о значају креативности и игралачког учења (в. Пијаже 1951, Виготски 1989), постоји притисак у оквиру целокупног образовног система који на директан или индиректан начин утиче на педагошке одлуке предавача, те њихову пажњу са процеса учења усмерава на производ. Ово је посебно наглашено у случају факултетског образовања где се лудички карактер учења додатно доводи у питање, будући да је институција факултета у многим културним моделима овенчана ореолом узвишене озбиљности.

Многе од ових тема релевантне су и за наставу страних језика. Традиционална настава језика која је усредсређена на структурне јединице језика не пружа ученицима прилике за креативну употребу језика, аутентичну комуникацију, а још мање за развој интеркултурне компетенције. У том погледу, у нашој земљи је постигнут значајан напредак током реформе образовања у првој деценији овог миленијума која је захватила све нивое језичког образовања, како у основној и средњој школи тако и на универзитетима. Значајан документ на који се ослања савремена настава језика у Србији управо је Заједнички европски референтни оквир за живе језике (Савет Европе 
Ана Јовановић

2001) у коме се заступа идеја да настава страног језика треба да омогући остваривање билингвалне/ плурилингвалне и бикултурне/ плурикултурне компетенције на основу које појединци стичу способност учешћа у интеркултурној интеракцији на два (или више) језика на различитим нивоима. „Овакво познавање језика нуди могућност упознавања већег броја културних заједница, размену искустава и шире могућности за радне и људске контакте“ (Вучо 2006: 42).

Преокрет у теорији о језику имао је за последицу постављање нових циљева у настави страних језика, а самим тим и замену метода који су до седамдесетих доминирали у учионицама страних језика. Ствара се повољна клима за постепено увођење комуникативног приступа. Иако комуникативни приступ није прескриптиван по питању појединачних аспеката језичке наставе, постоје јасне смернице за оптималну наставу језика у смислу активности, улога наставника и ученика, те наставног материјала. Наиме, у складу са идејом да треба створити услове за развој интеркултурне комуникативне компетенције, препоручују се активности усмерене на развој језичких функција са аспекта граматичке тачности, те прагматичке и социолингвистичке адекватности. Самим тим, заступљена је много већа разноврсност активности које се реализују на часу језика и у којима се тежи аутентичној комуникацији. Улоге наставника и ученика значајно су измењене у односу на традиционални модел у коме је студент пасивно следио наставникова предавања и упутства. У том циљу, значајна је примена различитих мотивационих стратегија којима се подстиче мотивација ученика и тежи њиховој већој аутонимији. Препоручује се, дакле, интерактивна настава језика која ученицима пружа прилику да активно уче и да се кроз употребу циљног језика постепено осамостаљују и оспособљавају за успешну употребу циљног језика у контакту са припадницима различитих култура.

У складу са поменутим променама, настава језика би на свим образовним нивоима требало да буде организована у складу са новопостављеним циљем остваривања интеркултурне комуникативне компетенције. Нажалост, стварност нуди 
ИГРАњЕ ИЛИ УЧЕЊЕ: НЕПОМИРЕНИ ДУАЛИТЕТИ У СТАВОВИМА...

нешто другачију слику, неретко због неблагонаклоних услова у којима се настава језика реализује. Међутим, чак и у околностима када постоје задовољавајући услови за реализацију комуникативне наставе, често су присутни превазиђени модели рада. Укорењени ставови о томе шта представља предмет изучавања језика и немогућност освешћивања имплицитних уверења можда су у извесној мери одговорни за потешкоће у ревитализацији наставе страних језика, које су препознате и у опсежној студији реализованој у оквиру TEMPUSS REFLESS пројекта (в. Вучо, Дурбаба 2012). У наставку рада ћемо се, стога, посветити квалитативној анализи ставова појединачних учесника наставног процеса који указују на извесне недоследности у ставовима о учењу и настави страних језика.

\section{3. Ставови учесника наставног процеса о настави страних језика}

\section{1. Наставници}

У време спровођења овог истраживачког пројекта на Катедри за иберијске студије Филолошког факултета у Београду (школска 2007-2008. година), нови програм учења и наставе шпанског језика био је имплементиран на првој и другој години студија, док су трећа и четврта година и даље пратиле наставу по старом програму. Наша испитаница Марија ${ }^{3}$ реализовала је наставу на другој и трећој години, што значи да је као страна лекторка имала обавезу да се држи два веома различита наставна програма. Ова чињеница нам даје могућност да упоредимо поступке исте особе у односу на два суштински различита наставна приступа.

Наиме, стари програм наставе шпанског језика при Катедри за иберијске студије подразумевао је предмет који се, заправо, састојао из више делова: превођење са шпанског на

3 Сва имена у раду представљају псеудониме како би се сачувала анонимност учесника у студији. 
Ана Јовановић

српски, превођење са српског на шпански, предавања и вежбе језичке структуре (фонетика и фонологија, морфосинтакса, лексикологија), те конверзација. Из ове поделе видимо да су настави језика у ужем смислу била посвећена само два часа недељно на вежбама из конверзације. Притом, сам програм није ни на који начин прецизирао који је теоријски оквир те наставе језика, који су њени непосредни циљеви и предвиђене активости. Нови програм, напротив, експлицитно наводи циљеве у смислу развоја комуникативне компетенције уз елементе хиспанских култура. По речима координаторке за Шпански језик, постојала је јасна веза између теорије и праксе при осмишљавању новог наставног програма (в. Јовановић 2009: 34-35). Идеја је да се створе услови за развој комуникативне компетенције првенствено у приватном, јавном и академском домену употребе језика кроз савремену наставу која се ослања на принципе теорије усвајања другог/ страног језика и савремене глотодидактике. Настави шпанског језика је, у време овог теренског истраживања, по новом плану било посвећено шест часова недељно.

Уколико се имају у виду одударања између новог и старог програма, требало би претпоставити да је реализација наставе на другој и трећој години веома различита. Стварност је пак другачија, као што су показали резултати истраживања са терена. Наиме, попис активности са часова друге и треће године студија не показују значајна одступања. Лекторка час обе године обично отвара спонтаним разговором о догађајима из протеклих дана у који се студенти укључују по сопственом нахођењу. Потом лекторка враћа исправљене и коментарисане есеје, након чега упућује студенте на страницу и број вежбања у уџбенику или радној свесци. Следећи распоред седења, студенти читају решења вежбања која се најчешће тичу изолованих језичких јединица (граматичке структуре и вокабулар). Лекторка повремено прекида активност како би објаснила поједине речи што јој неретко даје прилику за дигресије на теме културног садржаја (свакодневни живот и обичаји у Шпанији). У сврху увођења новог садржаја, лекторка се најчешће служи презентацијом: објашњава нову граматичку јединицу и 
ИГРАњЕ ИЛИ УЧЕЊЕ: НЕПОМИРЕНИ ДУАЛИТЕТИ У СТАВОВИМА...

прави изводе на табли, након чега налаже студентима да ураде контролисана вежбања из уџбеника. На крају обично уводи активност за слободнију употребу језика у виду писања пасуса или дужих текстова кроз рад у групи.

Овај приказ типичног часа указује да се лекторка води ППП протоколом, где након презентације новог садржаја следи увежбавање (пракса) праћено креативном употребом (продукцијом) језика. Такав след активности умногоме одражава поставке оралног приступа где се језички садржај уводи дедуктивно (Ричардс, Роџерс 1998: 37-48). Студентима се експлицитно објашњава нова језичка јединица чиме треба да се активирају њихови свесни процеси анализе; кроз увежбавање меморишу дату структуру да би им се у продукцији пружила прилика за креативну употребу језика. Нажалост, овакав приступ не оставља довољно простора за развој холистичке употребе језика. Без обзира на то што лекторка посвећује дужну пажњу и усменом и писаном језику, језику се не приступа холистички. Језичке јединице се уче изоловано и језик се третира као предмет изучавања, а не као средство комуникације или остваривања друштвених односа. За последицу, студенти су усредсређени на дату језичку структуру, те је спонтана употреба језика ометена чак и у случају креативнијих активности.

Захваљујући поновљеним интервјуима са лекторком, стекао се увид у њену наставну филозофију, ставове и одлуке који су утицали на реализацију конкретне наставе језика. Марија је током свог образовања углавном била изложена традиционалној настави језика коју није сматрала нарочито успешном. Своје течно знање више језика стекла је током продужених боравака у земљама где се ти језици говоре. С комуникативним приступом се упознала посредно, захваљујући специјализацији коју је реализовала у време кад се спроводило ово истраживање. Ипак је према савременом приступу неговала извесне резерве, те је у више наврата поновила да остаје „верна граматици“. Наиме, њено је мишљење да настава језика треба да упути студенте у основе језика, након чега може да уследи комуникација. 
Ана Јовановић

\begin{abstract}
Имају четири године да науче шпански, односно да науче основе шпанског, а језик не може да се научи за те четири године. Имаће касније времена да комуницирају, имаће после времена да прошире речник, да науче изразе, да науче остале ствари. Хоћу да кажем, ако имају основе у граматици, четири године живота за особу која се бави језицима нису ништа. То такође зависи и од личних циљева сваког студента. Свесна сам да у Сервантесу људи уче шпански да би разумели Серанове или да би ишли у Шпанију на одмор, или ради посла, разумем да желе да буде комуникативно, да желе да комуницирају. Али студенти на факултету, мислим да њихов циљ није да комуницирају, већ да буду филолози. Морају да имају солидније основе из граматике више него из свега осталог. (Марија, интервју бр.1: 33:20) ${ }^{4}$
\end{abstract}

Дакле, сврха наставе језика на универзитетском нивоу јесте проучавање језичке структуре у великој мери на начин на који то налажу структралистичке теорије језика (Ричардс и Роџерс 1998: 23-24). Комуникација долази као надоградња, вештина која се спонтано стиче уколико појединац поседује солидну лингвистичку компетенцију. Сходно томе, настава је организована на начин који ће студентима омогућити развој лингвистичке компетенције кроз дедуктивно изучавање граматике и вежбања контролисане употребе језика. На основу цитата можемо да видимо да је присутна неподударност лекторкине визије наставе језика са циљевима који су усвојени новим наставним програмом. Док савремена настава језика тежи да код кандидата развије све аспекте комуникативне компетенције, лекторкин приступ се превасходно усредсређује на развој лингвистичке компетенције.

У више наврата током истраживања појавило се питање шта представља адекватан приступ универзитетском образовању. По општеприхваћеном ставу, академско образовање за собом повлачи озбиљност и посвећеност професији која је, коначно, животно опредељење појединца. Међутим, овакав

4 Превод са шпанског А. J. 
ИГРАњЕ ИЛИ УЧЕЊЕ: НЕПОМИРЕНИ ДУАЛИТЕТИ У СТАВОВИМА...

став често за собом повлачи отпор према лудичком карактеру учења које заправо чини његов саставни део. Лекторка тако износи суздржаност према активностима отвореног типа које реализује са својим студентима друге године када постоји дужи блок наставе у трајању од три сата:

Кад их ставиш у групе, заиста помажу једно другоме; такмиче се групе, а ја сам одувек сматрала да је такмичарски дух важан. Сем тога, даје им другачију, па, другачију динамику. (...) Понекад помислим како не бих волела, не би ми се свидела таква вежбања да сам ја студент. Јер нисам дете да бих... Чини ми се помало детињасто. Чак и кад није. Чини ми се недовољно озбиљно за универзитет. Али пошто сам видела да добро реагују и да уживају... (Марија, интервју бр. 1: 24:30) ${ }^{5}$

Дакле, Марија настоји да у своју наставу унесе елементе игре, обично кроз групне активности које студенте укључују у креативно решавање проблема кроз имагинацију. Нажалост, такве активности се готово увек реализују пред крај часа када студентима пажња опада, те се преноси имплицитна порука да су од секундарног значаја за учење језика. Иако увиђа предност групних вежби и креативног ангажмана („помажу једни другима“, „даје им другачију динамику“, „добро реагују“, „уживају“), лекторка сматра да им није место на факултету. Напротив, суштину наставе језика на факултету чини фокус на граматику и увежбавање језичких структура, а на уштрб игре. Као што ћемо видети у наставку рада, ставови студената о карактеру наставе језика на факултетском нивоу не одударају значајно од ових уверења.

\section{2. Студенти}

Систем такав какав нам се набацује од средње школе па надаље, такав је да ти радиш граматику као граматику, и то не радиш кроз, кроз вежбе и тако неке игре, паралелно, да

5 Превод са шпанског А. J. 
Ана Јовановић

усвајаш као рецимо енглески који си чуо кад си прогледао отприлике па онда граматичке категорије можеш да примиш... Ове остале језике радиш одвојено и мислим да и деца имају тај проблем. Пошто он [лектор] свако мало има евалуацију (...), шта бисмо ми волели да радимо на часу, шта нам фали, у вези себе, шта нам он не пружа довољно, имали смо две-три после неких вежбања... не знам тачно... да ли нам се свиђа нека вежба, који делови вежбања нам се више свиђају који мање, и овај... пар нас је баш рекло да нам фали граматика. Његов одговор је био „граматику радите сами”, што можда и није толико лоше. Ако се претпостави да граматику радимо сами, значи да нешто ипак радимо и код куће, не чекамо само да дођемо да се зезамо на часу него да морамо мало озбиљније да схватимо и тај део. (Анабела, 18:25)

Испитаница Анабела је у време истраживања била на првој години студијског програма код лектора чији су часови у великој мери били одраз поставки савременог комуникативног приступа (в. Јовановић 2009: 62-68); у овом одломку дотиче неколико важних, међусобно тесно повезаних тема. Пре свега, студенткиња описује доминантан приступ у настави језика, такав какав је присутан од средње школе до универзитета. Наиме, граматика је постављена као циљ за себе, граматичке јединице се не уводе посредно као елементи комуникативне поруке, већ представљају окосницу око које се организује настава. Комуникативан приступ прикладан је само за учење енглеског језика, по мишљењу испитанице, будући да већ постоји значајно предзнање из језика условљено спонтаним усвајањем током свакодневног живота. Штавише, познавање језика је, судећи по цитату, предуслов за разумевање граматичких категорија.

Друга значајна тема одломка јесте став испитанице према настави граматике на часу шпанског језика на првој години студија. Њено је мишљење да је заступљеност граматике недовољна, те да би на самом часу већу пажњу требало посветити објашњењу и увежбавању граматичких категорија. Међутим, наставник језика је објаснио да у оквиру комуникативне методе нема много простора за експлицитну наставу граматичких 
ИГРАњЕ ИЛИ УЧЕЊЕ: НЕПОМИРЕНИ ДУАЛИТЕТИ У СТАВОВИМА...

јединица, а уколико сами студенти препознају властите пропусте у знању и разумевању одређених граматичких јединица, требало би да се том проблему самостално посвете, у раду код куће. Ову поруку, ипак, студенткиња није у потпуности исправно интерпретирала. „Ако се претпостави да граматику радимо сами, значи да ипак нешто радимо и код куће, не чекамо само да дођемо да се зезамо на часу него да морамо мало озбиљније да схватимо и тај део“, каже Анабела. Изнова видимо како се граматика опажа као окосница језичке наставе, састојак који читавом предмету даје нужну тежину, академску димензију. То је део који студент треба да савлада у раду код куће, јер, коначно, учење мора да буде озбиљно. Самим тим, тежиште наставе страног језика и даље је на лингвистичкој компетенцији.

Наставникова порука је погрешно протумачена јер се супротставља доминантном искуству у учењу језика и увреженим, општеприхваћеним ставовима о томе како се језик учи. Наиме, пре него што дођу на факултет, студенти су већ изложени настави страних језика у образовном контексту, некад од првог или трећег, а свакако од петог разреда основне школе, што чини најмање осам година континуиране наставе језика. Судећи по коментарима испитаника, у великој већини случајева та је настава често организована на традиционалан начин где се пажња претежно посвећује увођењу и објашњавању граматичких јединица. Савремене методе су ретко заступљене, било због неадекватних услова за рад (велики број ученика, недостатак наставног материјала, недовољна опремљеност наставног простора и др), било због самог наставног приступа. Услед тога, када се коначно сусретну с наставом која можда и боље одговара њиховим потребама и интересовањима, студенти често нису спремни да је одмах пригрле. „Ти долазиш, значи, од петог [разреда], рецимо, па надаље, са једним шаблоном учења и онда се овде шалташ сада на неки други. Јер ти знаш да си овамо радио нешто што су ти сви говорили да је битно, а тога сад немаш овде. Ти не знаш сад на који начин тај део да савладаш..." (Анабела 01:12:20).

Повремене дискусије на тему наставне методе такође нису довољне да код студента изазову значајније преиспитивање уверења, као што се да наслутити из следећег пасуса: 
Ана Јовановић

Имали смо баш то на једном часу, као граматика није најбитнија за један језик, битно је, као, да се разуме, па је маса њих рекла зато што кад одеш ти у Шпанију, нико ти неће дати тест из граматике, него ћете причати. Ја сам рекла ок, али ја волим да знам. Како, бре, да не знаш граматику? Мислим, како ћеш знати? Ти не учиш ово да би била, као, упућена у језик, него учиш да га знаш. Мора да ти буде колико толико битно. (Славица, 01:25:00)

Наравно, граматика треба да има значајно место на часу страног језика јер познавање језичких структура, коначно, представља услов за стицање лингвистичке компетенције као једне од димензија комуникативне компетенције. Међутим, поставља се питање како интегрисати граматику у наставу. Наиме, ако се на часу језика уводе и увежбавају граматичке јединице кроз дедуктивни приступ, ако се велика пажња посвећује „тачности“ исказа, при чему не остаје довољно времена за реалну употребу језика, доводи се у питање могућност примене комуникативног приступа. Напротив, настава језика која тежи развоју свеукупне комуникативне компетенције оставља више простора за увођење разноврснијих активности, веће слободе за преузимање и опробавање различитих улога, те приступ учењу који у већој мери уважава индивидуалне разлике студената. Студенти стичу више самопоуздања у процесу учења те сами траже нове прилике за употребу језика. Постепено постају спремни да се осамостале и прерасту у независне кориснике циљног језика.

Међутим, чак и кад се увере у ефикасност алтернативног приступа настави језика, као што је био случај са студентима на првој години студија у овом истраживању, негује се скептицизам према новој методи. „Постоји страх од тога“ (Ена, 16:10), постоји бојазан да уколико се материја савладава одвише лако, нешто од кључног значаја остаје ван досега студента. Коначно, немогуће је повезати идеје учења и игре, у нашем свету учење не може бити забавно.

Нама који нисмо радили [шпански], то је на неки приступачан начин објашњено све лепо и онда је, не знам... (...) 
ИГРАњЕ ИЛИ УЧЕЊЕ: НЕПОМИРЕНИ ДУАЛИТЕТИ У СТАВОВИМА...

Опет, за факултет, са тим неким сличицама и тако, изгледа да је неозбиљно. Али за прву годину док се не научи све, значи кад се учи мало-по-мало, мислим да је сасвим довољно. Али опет за другу годину чисто неке активности да се промене и, не знам... не [наш лектор], начин на који он нама прича, него једноставно неке активности да мало озбиљније, да се мало више укључимо, да мало више размишљамо како шта, да... Не кажем да се мучимо, али буквално тако некако, да нам буде тешко да бисмо још боље научили. (...) Ја осећам понекад да бих волела мало више да радим, да ми буде теже зато што... Немам појма... Кад ме питају како ти је на факултету, ја кажем добро, не знам шта под тим мислим. (Мара, 01:05:30)

Као да слушамо разговор између две особе од којих једна брани право да се учи на један пријемчив и занимљив начин, док друга захтева да се у процес наставе уведе дужна доза озбиљности и патње. И коначно, не зна шта да мисли. Није за чуђење будући да се позитивно искуство стечено на часовима шпанског језика практично супротставља њеном ранијем образовању, као и усвојеном културном моделу.

\section{4. Закључак}

Ставови учесника наставног процеса изграђују се на основу доминантне образовне идеологије и представљају њену конкретизацију: општеприхваћена, некад и имплицитна уверења изражавају се кроз исказе појединаца и дају нам могућност да боље разумемо културни модел који управља одлучивањем и поступањем у наставном контексту. У случају наших испитаника, изгледа, постоји јасан дуалитет између учења и игре, који се отелотворује кроз сукоб граматике и игре, озбиљног и забавног. Природно се намеће питање како помирити ове наизглед опречне крајности будући да су нам обе потребне за квалитетну и успешну наставу страних језика. 
Ана Јовановић

Резултати истраживања потврђују да није довољно само увести нови програм, без обзира колико напредан, и очекивати да ће његови корисници бити у стању да га на прави начин пригрле. Идеологија образовања је сувише снажна и дубоко укорењена да би једно ново и позитивно искуство могло да је промени. Стога је потребно да се актери образовног процеса укључе у процес наставе и педагошких одлука на начин који им даје увида како се доносе одређене одлуке и зашто се спроводе конкретни поступци. Примера ради, треба објаснити зашто се од студената тражи повратна информација, зашто се од њих очекује да сами изаберу тему за презентацију, зашто се уводе језичке игре, итд. Нажалост, у оквиру наставе језика често нема довољно времена за систематично бављење овим питањима те би требало размислити и о могућностима увођења метакогнитивног тренинга кроз наставу језика.

Чињеница да се овде ради о настави језика организованој на универзитетском нивоу још више наглашава озбиљност појаве. Наиме, није довољно да предавачи и студенти буду упознати са савременим токовима науке о језику јер то не утиче значајно на промену њиховог приступа настави, односно учењу језика. Од кључне је важности створити услове да учесници преиспитају своја дубока уверења и ставове о настави језика, како би се и њихово деловање суштински променило.

\section{ЛИТЕРАТУРА}

Виготски 1989: Виготски, Л. С. Развој, учење и игра. Превео Киро Поповски. Скопје: Просветно дело.

Вучо 2006: Вучо, J. У потрази за сопственим моделом двојезичне наставе, у: А. Вујовић, И. Радовановић, Б. Требјешанин (ур.), Иновације у настави страних језика, Београд: Универзитет у Београду, Учитељски факултет, 41-54.

Вучо, Дурбаба 2012: Вучо, J. Д., Дурбаба, О. М. Криза филолошких студија: ставови студената и наставника о усклађености студијских садржаја, наставе и потреба савременог друштва, у: М. Ковачевић, Д. Бошковић (ур.), Савремено друштво и криза проучавања језика и књижевности, Крагујевац: ФИЛУМ, 123-139. 
Голинкоф, Сингер, Хирш-Песек 2006: Golinkoff, R. M., Hirsh-Pasek, K., Singer, D. G. Why play = learning: a challenge for parents and educators, in: Play=Learning: How play motivates and enhances children's cognitive and socio-emotional growth, New York, NY: Oxford University Press, 3-14.

Жиру, Парпел 1983: Giroux, H., Purpel, D. (Eds.) The hidden curriculum and moral education. Berkeley, CA: McCutchan Publishing Corporation.

Јовановић 2009: Jovanović, A. Student and teacher attitudes in foreign language instruction. Belgrade: Andrejević Endowment.

Јовановић 2012: Јовановић, А. (2012). Идеологије образовања и рецепција страних језика, у: М. Ковачевић, Д. Бошковић (ур.), Савремено друштво и криза проучавања и рещепције језика и књижевности, Крагујевац: ФИЛУМ, 141-154.

Јовановић 2016: Jovanović, A. Waking up from the university dream: Intersection of educational ideologies and professional identity construction. Saarbrücken: Lambert Academic Publishing.

Јовановић 2017: Jovanović, A. Language education and philological studies: perspectives for an integrative approach, V. Dickov (ed.), Identidad, mobilidad y perspectivas de los estudios de lengua, literatura y cultura, Filološki fakultet Univerziteta u Beogradu, Università degli Studi "Gabriele d'Anunzio" Chieti - Pescara, 247-262

Миган, Харбер 2007: Meighan, R./ Harber C. A sociology of education. 5th edition. London: Continuum.

Пијаже 1951: Piaget, J. Play, dreams, and imitation in childhood. New York, NY: Norton.

Ричардс и Роџерс 1998: Richards, J. C., Theodore S. R. Enfoques y métodos en la enseñanza de idiomas. Cambridge: Cambridge University Press.

Савет Европе 2001: Council of Europe. Common European framework of reference for languages: Learning, teaching, assessment. Cambridge, UK: Cambridge University Press.

Сингер, Сингер 2005: Singer, D. G., Singer, J. L. Imagination and play in the electronic age. Cambridge, MA: Harvard University Press. 
Ана Јовановић

\title{
Ana Jovanović \\ TO PLAY OR TO LEARN: OPPOSED DUALITIES IN FOREIGN LANGUAGE TEACHER AND STUDENT ATTITUDES
}

\begin{abstract}
Summary
According to the current theories of language, the goal of language teaching is a development of intercultural communicative competence so that the student can become a successful and autonomous language user. Although these ideas are generaly accepted on different levels of organization and implementation of the foreign language instruction, the data obtained through a qualitative research at the School of Philology in Belgrade show that sometimes teachers and students do not fully appreciate these principles which has negative consequences for the actual language instruction. Even when they are familiar with the ideas of contemporary communicative approach, it is not rare that students and teachers remain fairly traditional in their beliefs and attitudes toward language learning and teaching. These beliefs are related to the deeply rooted expectations about the university education, perceived as a studious, hard endeavor dedicated to the accumulation of new information. Playfulness is practically excluded from this process, which undermines the natural relationship between learning and play. For a systematic change to actually occur in the foreign language classroom, it is important that the participants in the learning process (teachers and students) reconsider their beliefs about language education in specific and university education in general. Some kind of a metacognitive training should be considered at the earlier stage of the (university) education.
\end{abstract}

Key words: attitudes, communicative approach, education ideology, foreign language teaching, playfulness, teaching grammar. 